\title{
Integrative and Disintegrative Ideologemes in Russian Media-Political Discourse
}

\author{
Azaliya R. Gizatullina, Milena I. Gumerova, Gulnara F. Lutfullina, Irina V. Vashunina
}

\begin{abstract}
The semantic field of political discourse is based on the opposition of «ours - theirs» which content varies depending on the state system and the power regime. Post-perestroika discourse has undergone fundamental transformations associated with the breakdown of previous semantic links and the subsequent building of new ones.

The study is devoted to understanding the ideological system of the post-perestroika period. Within the media-political discourse (on the material of collecting samples from daily newspaper «Izvestia», 1992) the interrelationship of two thematic groups of ideologemes is analyzed: integrative ideologemes and disintegrative ideologemes. The descriptive method, methods of linguo-cognitive and linguo-ideological analysis, as well as quantitative methods are used in this article.

We characterized the system of integrative and disintegrative ideologemes that were developed in the early post-perestroika period. Ideologemes are described in accordance with Russian linguist O.S.Issers's classification. The significance of integrative and disintegrative ideologemes in the early post-perestroika discourse is universal and relevant to each world ideological picture in order to distinguish internal and external state images of «ours - theirs».
\end{abstract}

Keywords: ideologeme, thematic groups, integrative ideologemes, disintegrative ideologemes, opposition «ours theirs», post-perestroika, media-political discourse.

\section{INTRODUCTION}

Today in political discourse the struggle for political power is largely carried out by non-institutional means, by the media which is largely named as a «fourth power». If a political party manages to prove the worthiness of its ideological image, it wins.

At the same time, the ideological content of modern political language isn't sufficiently studied in comparison with Soviet regime political language which is often named «wooden language».

Russian political discourse has developed from Soviet political discourse, which was based on the opposition «ours theirs» On the material of the newspaper «Izvestia» [Izvestia] we identified 8 key thematic groups ${ }^{1}$ of ideologemes that implement the opposition «ours - theirs».

\section{MATERIAL AND METHODS}

A lot of researches in Russia and abroad are devoted to the political discourse: it is thinking on modern media-political

Revised Manuscript Received on November 08, 2019.

* Correspondence Author

Azaliya R. Gizatullina, Kazan Federal University

Milena I. Gumerova, Kazan Federal University

Gulnara F. Lutfullina, Kazan State Power Engineering University

Irina V. Vashunina, Russian Foreign Trade Academy, RUDN University, Moscow State Linguistic University

discourse [Harkova 2014; Muhametzyanova 2017; Sheigal 2000; Yapparova 2018 et al.], perestroika political discourse and post-Soviet discourse [Budaev 2009; Dunn 1995; Koteyko 2014 et al.], the ideological component of political discourse [Erol 1993; Klushina 1996; Malysheva 2009; Robinson 1995; Shevchenko 2017 et al.].

We identified 8 key thematic groups of ideologemes $(1,658$ ideological uses) by collecting and analyzing samples from 281 issues of the newspaper «Izvestia» (1992). The choice of this time interval is due to the fact that year 1992 is considered as a start point for studies of newest political discourse [Budaev 2009: Kor, et al 2019]. The newspaper «Izvestia» positions itself as an independent newspaper edition, therefore, it expresses the diversity of opinions, which reflects the post-Soviet discursive space.

According with linguistic-cognitive approach the term «ideologeme» is understood as a mental unit which includes an ideological component (including evaluation and repeatability in the discourse) and which is expressed by a lexeme (or statement) in the text and discourse.

Two groups of ideologemes are analyzed in the given article. These ideologemes are involved to develop the key opposition «ours - theirs»: integrative ideologemes (share of usages- $7.4 \%$ ) and disintegrative ideologemes (12.4\%). The frequency of these ideologemes is rather low in comparison with other groups of ideologemes such as «USSR» (22.1\%), «Democracy» $(15.3 \%)$. However they are very important because they allow to determine the means by which ambiguous assessment was expressed and they allow to discover the means by which world picture was rebuilt after perestroika period.

The method of descriptive and linguo-cognitive analyses, the method of linguo-ideological analysis as well as quantitative methods are used in this article.

\section{RESULTS}

Reaching beyond totalitarian discourse made possible negative assessments of not only «enemies», but also «friends». Unlike the totalitarian discursive space democratic discursive space uses various means. On the one hand these means allow to smooth asymmetry in the coverage of a political event. On the other hand - create models to express freedom and diversity of opinions due to existed ideological centers.

Democratic discourse functions in accordance with a stable scheme «ours - theirs». The basic difference between a democratic communicative space and a totalitarian space is the greater semantic implicitness which makes possible to veil the ideological component. 


\section{Integrative And Disintegrative Ideologemes In Russian Media-Political Discourse}

In this article we distributed selected ideologemes in accordance with the classification proposed by E.G.Malysheva [Malysheva 2009: 37].

From different points of view integrative ideologemes and disintegrative ideologemes are classified:

1) as universal ideologemes depending on their relevance / irrelevance to 1992 year's ideological world picture; on their participation in realizing basic opposition «ours - theirs»;

2) as commonly used ideologemes identically understood by different representatives of political opinions;

3) taking into account their pragmatic component [Sheigal 2000: Nuriyev, et al 2018] as integrative ideologemes or idyllic ideologemes (they affirm positive values and support current state ideology) and as disintegrative ideologemes or nightmare ideologemes (they personify evil power).

In addition these ideologemes are distributed into groups in accordance with O.S.Issers's classification [Issers 2008: Mardani, \& Fallah 2018]. She considers speech action impact as one of operations on semantic networks characterized by discontinuity (the most frequent scheme in the selected contexts «A is not $\mathrm{B} »)$ and by establishment of new associative dependencies (the most frequent schemes in the selected contexts «A is $\mathrm{B} »$ and «A has a sign of $\mathrm{B} »)$.

I. Integrative ideologemes.

During perestroika the Soviet mythological system was destroyed. A part of ideologemes were created on the contrast «new reality» - «former order». A part of ideologemes - on the basis of successiveness. Integrative ideologemes include: великая держава / great power, единый / unified ${ }^{2}$, интеграционный / integrative, интересы / interests, отношения / relations, партнерство / partnership, nреемница союза CCP/ successor of the Union of the USSR, равный / еqual, Россия / Russia, связи / communications, CHГ / CIS, Coдружество / Commonwealth, соседи / neighbors, сотрудничество / cooperation, член (содружества, сотрудничества, РФ) / member of (community, cooperation, $R F$ ) et al.

It should be noted that these ideologemes did not correspond to political interests of the national leaders of the CIS countries. For example, post-Soviet discourse ideologeme «нерушимая дружба народов» / «indestructible friendship of nations» was denounced [Klushina 1996: Martínez-Alcalá, et al, 2018] that's why this ideologeme has the low frequency in this group.

Here we observe a curious situation of shifting the image «enemy» into the image «internal enemy». The ideologeme was used to consolidate the multinational population. This ideologeme represents the nationalists as a hostile force: «The most understandable enemy in this case is Ukraine, nationalists» ... (Izv.,1992,50,02 $\left.{ }^{3}\right)-\mathrm{A}$ (the enemy) is $\mathrm{B}$ (the nationalists).

In one of the issues of the newspaper is noted: «in Russia "enemy search" is gradually moving from "ideological soil to national soil" »(Izv.,1992,185,08) - A (searching for the enemy) has a sign of B (moving to the national soil).

These internal integrative ideologemes are traditionally built on the basis of the opposition «ours - theirs».

At the same time there are external «ours»: «The West is a natural ally of the new Russia» (Izv.,1992,13,01) - A (West) is $\mathrm{B}$ (ally).
A characteristic feature of the integrative ideologemes is a focus on the future or the past. Soviet integrative ideologemes inspired people by Future or by distant bright goal which could be reached only due to the cooperation. Post-Soviet integrative ideologemes may focus on Past (common values, history): B.Yeltsin said: «United Russia was, is and will be. National history will not be interrupted» (Izv.,1992,78,04) A (United Russia) has the sign of B (was, is, will be); also on Future. In this case they express dissociation with Soviet time principles and the search for new principles (equality, partnership, cooperation): «Russia does not want to pursue an imperial policy. Russia wants to cooperate and to trade on equal terms as well as to conduct political dialogue without pressure» (Izv.,1992,162,07) - A (Russia) has the sign of B (does not want to pursue an imperial policy, wants to cooperate equally).

II. Disintegrative ideologemes.

This group of ideologemes flooded the media in 1992 due to relentless interethnic conflicts indicating the process of awakening national interests and the beginning of the formation of a national myth, since «ideology imposes a dominant value system, which is reflected in the semantics of mythology» [Sheigal 2000: 183].

Disintegrative ideologemes include: агрессия / aggression, (взаимо)отношения / (mutual) relations, вооруженные силь / armed forces, границьь / borders, дележ / division, единый / unified, защищщать / to defend, интересы / interests, конфликт / conflict, национализм / nationalism, националист / nationalist, начионалистический / national, (про)имперский / (pro-)imperial, разногласия / disagreements, раздел / division, разрыв / gap, Россия / Russia, русский / Russian, свой / own, связи / communications, сепаратизм / separatism, сила / force, CHГ / CIS, Содружество / Commonwealth, cnop / dispute, суверенный / sovereign, территория / territory, Украина / Ukraine et al.

A part of the ideologemes of this group creates an image of an ethnic enemy and serves as a means of expressing aggression: «Caucasians (Chechens, Azeris, etc.) have clung to Russia from all sides and divided Russia into zones of influence. It is worse than the Tatar-Mongol yoke» (Izv.,1992,107,05) - A (Caucasians) has the sign of B (they divided Russia); «Russia disintegrates into many parts from the suburbs and almost to the center. Tatars of Kazan, Crimea and the Caucasus will tear Russia apart into pieces» (Izv.,1992,169,07) - A (Russia) has the sign of B (disintegrates), A (Tatars) has the sign of B (they tear Russia apart).

The ideologeme «own» has been mainstreamed: «Tatarstan's foreign policy is also its own policy» (Izv.,1992,163,07) - A (Tatarstan) has the sign of B (its own foreign policy); «Ukraine ... will go its own way - just like Turkmenistan» (Izv.,1992,225,10) - A (Ukraine) has the sign of B (its own road); «Belarus, Moldova, Armenia and Azerbaijan remained in their own interests» (Izv.,1992,225,10) - A (Belarus, Moldova, Armenia, Azerbaijan) has the sign of B (its own interests).

The expansion of national ideologemes is also associated with relentless national conflicts. At the level of national construction the idea of a «titular nation» is declared, all other nations must be imbued 
with this idea: «Nationalism like child measles has become a growing pains of sovereignty of the former fraternal republics» (Izv.,1992,50,02) - A (nationalism) has the sign B (growing pains of sovereignty).

In Russia this process was supported by the ideologeme «Россия/Украина - правопреемница СССР» / «Russia/Ukraine is a successor of the USSR» which appealed to the former power of the former state. This ideologeme began to revive the archetypical image of the Orthodox God-bearing people [Tsuladze 2003: 193] which has unique spiritual qualities allowing to claim a leading role among other CIS states: «Russia and Ukraine have declared themselves as the successors of the former USSR under the existing international agreements» (Izv.,1992,24,01) - A (Russia, Ukraine) is B (the successor of the USSR).

The resilient and expansionist tendency associated with an attempt to revive the empire on national soil [Tsuladze 2003: President of Ukraine accuses Russian leaders of manifesting imperial ambitions» (Izv.,1992,12,01) - A (Russian leaders) has the sign of B (imperial ambitions).

Due to the presence of opinions pluralism the same lexemes can be filled with a positive or negative assessment and perform integrative or disintegrative ideological functions: «The CIS will exist for a long time. For us the Commonwealth some common denominator « (Izv.,1992,89,04) - A $(C I S)$ is any special joy to any of the parents» (Izv.,1992,206,09) - A $(C I S)$ is B (weak, painful child).

Contradictions in matters of national interests and the between the leading CIS countries - Russia and Ukraine. We have singled out the «Crimean Question» ideologemes as an independent group. Part of the ideologemes of this group is associated with integration and disintegration, the implementation of the ideology of multiculturalism in them is indicative: «Of course, the Crimea will never be Ukrainian! But it has never been Russian, that is the question» (Izv.,1992,50,02) - A (Crimea) is not related to B (Russian, Ukrainian); «If Russian patriots go to «not give up» the Crimea and Odessa, then there is no doubt that Ukrainian patriots will stand in their way. And each of the parties will consider itself a defender of justice» (Izv.,1992,49,02) - A (Russian and Ukrainian patriots) is B (a defender of justice).

\section{DISCUSSION}

The restructuring of the state system entailed the need to rethink the existing ideological system. In many contexts of the newspaper «Izvestia» in 1992, metaphorization of ideologemes are found: «And also the Crimea. Refusing to even discuss its status, did the parties find themselves in the position of a patient who is afraid of the inevitable operation more than of the disease itself « (Izv.,1992,147,06) - A (the side regarding the Crimean question) is $\mathrm{B}$ (the patient).

From the point of view of the linguo-cognitive approach, metaphors are a sign of crisis thinking, when a paradigm change exists in the minds of native speakers. Metaphores help to look at the problem from a new angle, to identify possible alternatives, among which a choice can be made later. 231] was negatively assessed in the post-Soviet space: «The is a kind of school. We learn to work in conditions of independence of states, to bring the interests of these states to B (school); «CIS is a weak, painful child which doesn't bring desire for leadership led to the aggravation of relations

It should be borne in mind that ideologemes become the basis for the formation of a mythologized consciousness. The emergence of polyphony in the information space of the early post-perestroika period allows us to consider the system of ideologemes emerging at this stage and the nascent myths of modern Russia.

\section{V.SUMMARY}

The analysis conducted by A.N.Baranov [Baranov 1990: 42] shows that the political communication of the perestroika period was centered around two value poles, one of which was Justice and Equality, and the other was Freedom.

Our article confirms the relevance of these polar points for the start of the post-perestroika period. Ideological systems of representatives of different views are formed on the basis of these two polar points. Integrative ideologemes (интересbl (общие) / interests (common), nартнерство / partnership, равный / еqual, Содружество / Commonwealth, etc.) and disintegrative ideologemes (границы / borders, интересы (личные) / interests (personal), свой / own, суверенный / sovereign, etc.) are also formed on the basis of these two polar points.

\section{CONCLUSIONS}

In today's information society it is difficult to overestimate the role of the media which acts as an intermediary for the information we receive.

Ideology is an integral part of any society, it organizes our perception of the world, it affects the public consciousness. The archetypal opposition is «ours - theirs», which is characteristic for the totalitarian discourse and for the democratic one. The only difference is that the democratic discourse can acquire several ideological centers and a greater implicitness, as well as the ability to form the image of the internal «enemy». These trends were traced by us on the example of thematic groups of integrative and disintegrative ideologemes on the material of media-political discourse in the early post-perestroika period.

\section{ACKNOWLEDGEMENTS}

The work is performed according to the Russian Government Program of Competitive Growth of Kazan Federal University.

\section{REFERENCES}

1. Izvestia [Izvestia]. 1992. Ianvar' - dekabr'. No.1 - 281. (In Russian)

2. Harkova, E.V., Shigapova, F.F. (2014). Functional features of metaphoric and metonymic euphemisms in media discourse. European Journal of Science and Theology. Vol.10. No.6, pp. 105-113.

3. Muhametzyanova, L.R., Mardieva, L.A. (2017). The Polyfunctuanality in The Names Of Newspapers And Magazines. Revista San Gregorio, Spec. Edit., pp. 148-153.

4. Sheigal, E.I. (2000). [Semiotics of Political Discourse]: dis. ... d-ra filol. nauk. 431 p. Moscow. (In Russian)

5. Yapparova, V.N., Ageeva, Ju.V., Agmanova, A.Y. (2018) Pre-Election Discourse as a Special Type of Institutional Discourse. HELIX. Vol. 8, Is.1, pp.2324-2327.

6. Budaev, E.V., Chudinov, A.P. (2009). [Linguistic Sovietology]. 291 p Ekaterinburg. (In Russian)

7. Dunn, J. (1995). The transformation of Russian from a language of the Soviet type to a language of the Western type.In J. Dunn (ed.) Language and Society in Post-Communist Europe.Selected Papers from the 5th World Congress of Central and Eastern 
European Studies.Warsaw, pp. 3-22.

8. Koteyko, N. (2014). Language and Politics in Post-Soviet Russia: A Corpus Assisted Approach. London: Palgrave Macmillan, XI, 191 p.

9. Erol, N. (1993). Ideology as political discourse: a case study of print media discourses on Glasnost and Perestroika. East Lansing: Michigan State University.

10. Klushina, N.I. (1996). [Speech Means Mythologization in Modern Newspaper Language]. Russkaya rech'. No.5. Moscow, pp. 36-42. (In Russian)

11. Malysheva, E.G. (2009). [Ideolodeme as a Cultural Phenomenon: Definition and Classification]. Politicheskaya lingvistika. No.4 (30), pp. 32-40. (In Russian)

12. Robinson, N. (1995). Ideology and the collapse of the Soviet system. A critical history of Soviet ideological discourse. Aldershot: Edward Elgar, X, $227 \mathrm{p}$.

13. Shevchenko, A.R., Nasrutdinova, L.H., Dubrovskaja, S.A. (2017). Mythologization of the soviet reality and istorization of «the soviet myth» in the russian prose of the end of the XX century. Journal of history culture and art research, pp. 174-176.

14. Issers, O.S. (2008). [Communicative Strategies and Tactics of Russian Speech]. 288 p. Moscow. (In Russian)

15. Tsuladze, A.M. (2003). [Political Mythology]. 384 p. Moscow. (In Russian)

16. Baranov, A.N. (1990). [Linguistic Argumentation Theory (Cognitive Approach)]. Avtoref. dis. ... d-ra filol. nauk. Moscow. (In Russian)

17. Mardani, M., \& Fallah, R. Comparison of Financial Leverage Ratio before and after the Use of Off-Balance Sheet Financing in Firms Listed in the Tehran Stock Exchange. Dutch Journal of Finance and Management, 2(2), (2018).53. https://doi.org/10.29333/djfm/5829

18. Martínez-Alcalá, C. I., Ramírez-Salvador, J. A., Rosales-Lagarde, A., \& Jiménez-Rodríguez, B. Assistance and Support of Primary Caregivers through an eService Platform. Journal of Information Systems Engineering \& Management, 3(1), (2018). 09.

19. Kor, L., Teoh, S., Binti Mohamed, S. S. E., \& Singh, P. Learning to Make Sense of Fractions: Some Insights from the Malaysian Primary 4 Pupils. International Electronic Journal of Mathematics Education, 14(1), (2019). 169-182. https://doi.org/10.29333/iejme/3985

20. Nuriyev, M., Sovetkanova, D., \& Seysenbayeva, Z. Achievements and new challenges in the area of education of independent Kazakhstan. Opción, 34(85-2), (2018). 337-352. 